\title{
Virology and Histopathology of the Trigeminal Ganglia of Americans and Japanese
}

\author{
K. G. WARREN, Z. WROBLEWSKA, H.OKABE, S. M. BROWN, D. H. GILDEN, H. KOPROWSKI. \\ L. B. RORKE, J.SUBAK-SHARPE. AND T. YONEZAWA
}

\begin{abstract}
SUMMARY: Herpes simplex virus in the trigeminal ganglia of humans was studied in Philadelphia. Pennsylvania, United States of America. and in Kroto. Japan. The prevalence of recurrent herpes labialis and of clinically latent herpes simplex virus within trigeminal ganglia was determined in inhabitants of the wo cities. In addition. a comparison was made of the prevalence of mononuclear cell infiltration in the trigeminal ganglia of Americans and Japanese. Recurrent herpes labialis was found to be significanlly less common in the Japanese city than in the American city.
\end{abstract}

RÉSUMÉ: Le virus de l'Herpes simplex dans les ganglions trijumeaux fü étudié à Philadelphie (Pennsylvanie, U.S.A.) et à Kroto (Japon). La prélalence de l'herpes labialis récurrent et du virus de l'herpes simplex cliniquement latent. fut étudiée dans le ganglion trijumeau chez les habitants des deur villes. De plus nous avons comparé la prévalence de linfiltration en cellules monomucléarires dans le ganglion trijumeau des américains et des japonais. L'herpes labialis récurrent fut trouvé significativement moins souvent dans le ville japonaise. De même le virus de l'herpes

\footnotetext{
From the Multiple Sclerosis Research Centre of the Wistar Institute of Anatomy and Biology, and the Department of Neurology. Hospital of the University of Pennsylavania and the First Department of Pathology, Kyoto Prefectural University School of Medicine, Kyoto Japan and the Institute of Virology. University of Glasgow, Glasgow, Scotland.

Reprint requests to: Dr. H. Koprowski at the Wistar Institute of Anatomy and Biology. $36 \mathrm{~h}$ Street at Spruce, Philidelphia. PA 19104. USA.
}

Herpes simplex virus nas rescued less commonly from the trigeminal ganglia of cadavers in Japan than in America. The difference was significam. The frequency of mononuclear cell infiltration in the trigeminal ganglia of Americans and Japanese is not significantly different. These observations, as well as previous/! reported serological studies, suggest that despite the ubiquitous nature of herpes simplex virus in America and Japan, the Japanese have less clinically overt desease caused by this virus.

simplex est moins fréquent dans les ganglions trijumeaux de cadavres au Japon quien Amerique. Cette différence est significative. Cependant il n'y a aucune difference significative dans la fréquence des infiltrations monomucléaires entre les sujets des deux villes. Ces observations, couplées aux études sérologiques préalablement rapportécs, indiquent que malgré la nature ubiquitaire du virus de lherpex simplex en amérique et au Japon, les japonais semblent moins sujets aux manifestations cliniques de cette atteinte virale.

\section{INTRODUCTION}

Recurrent herpes labialis ( $\mathrm{RHL}$ ) is associated with the recurrent appearance of herpes simplex virus (HSV) in the circumoral tissues. When lesions are not present in the circumoral tissues, the virus is latent in the trigeminal ganglia. Recurrence of the lesions probably follows reactivation of the virus in the ganglia with subsequent passage of the virus distally along the maxillary and mandibular nerves to the circumoral tissues where a lesion occurs.

RHL occurs in over $35 \%$ of young adults in the United States and Canada (Ship et al., 1960; Warren et al., 1976), whereas in Asia RHL apparently affects less than $20 \%$ of young adults (Embil et al., 1975). This difference occurs despite the fact that serological studies suggest that $\mathrm{HSV}$ is equally prevalent in the Western Hemisphere and in Japan, with $75 \%$ of adults in both areas having demonstrable antibodies to the virus (Andrewes and Carmichael, 1930; Yoshino et al., 1962; Hondo, 1974). Therefore, on the basis of previous research, the Japanese appear to be less likely than Americans to develop overt clinical diseases caused by HSV, despite the ubiquitous presence of the virus in both populations. A previous Japanese histopathological study of the trigeminal ganglia of human cadavers has demonstrated mononuclear cell infiltrations in $50 \%$ of cases (lshizaki, 1972). While the exact function of these mononuclear cell infiltrations is unknown, they may be involved in maintaining HSV or other viruses in a clinically latent state.

The present investigation was undertaken in order to investigate: 1) whether RHL is less frequent in Japan than in America, as suggested by previous studies, 2)whether HSV can be isolated as frequently from the trigeminal ganglia of Japanese as from Americans, and 3)whether mononuclear cell infiltration of trigeminal ganglia is a common observation in America as it is in Japan.

\section{MATERIALS AND METHODS}

The data on the prevalence of RHL were obtained by administering a questionnaire (Figure 1) to adults in Japan and in the United States of America (USA). The questionnaires in Japan were administered to 245 university students, nurses, scientists, 
Figure l.

THE PREVALENCE OF HERPES LABIALIS (COLD SORES, FEVER BLISTERS) IN ADULTS*

1) Name (lnitials) (Optional)

2) Sex: Male Female

3) Age: $20-29$ years

30 - 39 years

$40-49$ years

$50-59$ years

$60-69$ years

$70+$ years

4) Date of birth:

5) Disease Category:

Normal Adult

Diseases (Name)

6) Have you every had cold sores or fever blisters around your lips?

YES NO Uncertain

7) Description of perioral lesion given by the patient:

8) How frequent are your cold sores or fever blisters?

Less than once a year

1 - 2 per year

3 - 4 per year

5 - 10 per year

9) Do any of the following factors cause a recurrence of your cold sores or fever blisters? Prolonged sunlight

Menstrual periods

Dietary peculiarities (e.g., chocolate)

Fatigue

Infections

Other (name)

*The questionnaires were administered in Japanese in Japan.

and technicians. In the USA the questionnaires were administered to 146 university students and to technicians and scientists. The respondents were between 19 and 51 years of age. All respondents were familiar with or were informed of the clinical features of RHL. The significance of the difference in prevalence of RHL in Americans and Japanese was calculated by a Chi square test.

Virus isolation studies on the trigeminal ganglia were performed by the same personnel in America and Japan, using similar techniques in both countries. Virus isolation studies were performed on 52 trigeminal ganglia obtained from 29 cases autopsied in Japan: 11 during MarchApril and 18 during August-Septem- ber, 1977. There were 16 males and 13 females. Twenty-five of 29 patients were over 50 years of age, 2 were between $30-40$ years of age, and 2 were under 10 years of age. All cases studied in Japan had severe subacute to chronic debilitating diseases. Visceral cancers were the cause of death in 18; neurological diseases (Jakob-Creutzfeldt disease, amyotrophic lateral sclerosis, astrocytoma) in 4; liver and kidney disease (Laennec's cirrhosis, hepatoma, polycystic kidney disease and chronic renal failure) in 5; and heart disease (rheumatic valvular disease and coronary artery atherosclerosis) in 2. All cases in America died subsequent to trauma, except for two patients who had either a lymphoma or multiple sclerosis. The majority of the patients were 20 to 50 years of age.

The method of removal of trigeminal ganglia for virus isolation studies from cadavers in Japan was similar to that previously reported by our laboratory on HSV isolation from the trigeminal ganglia of American cadavers (Warren et al., 1977). In Japan each ganglion was explanted into 4 plastic Falcon 25-cc. flasks (11 cases) or into 2 plastic Falcon 25-cc. flasks and 2 glass, 16-ounce prescription bottles (18 cases). Growth medium consisted of Leibovitz-15 medium supplemented with $50 \%$ fetal bovine serum (FBS), penicillin (100 $\mathrm{U} / \mathrm{ml})$, and streptomycin $(2 \mu / \mathrm{ml})$. Fragments of ganglia from the last 18 cases were also cocultivated with African green monkey kidney cells (CV1) in plastic Falcon 25-cc. flasks, using Eagle's minimal essential medium supplemented with glutamine, $10 \% \mathrm{FBS}$, and antibiotics as described above for Leibovitz-15 medium ( $\mathrm{E}+$ 10). The explants and cocultivated cultures were incubated at $37 \mathrm{C}$ in $5 \%$ $\mathrm{CO}_{2} 95 \%$ air. All cultures were monitored regularly for a minimum period of 6 weeks for the development of viral cytopathic effect (CPE). The growth medium was changed weekly and the cocultivated cultures were subpassaged 2-3 times by trypsinization.

If viral CPE occurred in the monolayers, $1.0 \mathrm{ml}$ of the unclarified medium was inoculated onto a fresh monolayer of CVI cells or WI 38 cells in 25-cc. plastic flasks. After 1 hour of virus absorption at $37 \mathrm{C}$ the inoculum was removed, and the cultures were refed with fresh $\mathrm{E}+10$ and incubated at $37 \mathrm{C}$ in $5 \% \mathrm{CO}_{2}, 95 \%$ air. When viral CPE again appeared, the cells were scraped into the tissue culture medium, resuspended and frozen at $-80 \mathrm{C}$ in $1.0 \mathrm{ml}$ aliquots.

The isolated viruses were identified by a seroneutralization test, using one concentration of hyperimmune rabbit anti-HSV type 1 and anti-HSV type 2 sera and various doses of virus ranging from $1-10^{7}$ tissue culture infectious doses (TCID) so $_{0} / 0.025 \mathrm{ml}$. The mixtures of virus and sera were incubated for 1 hour at $37 \mathrm{C}$ and then were inoculated onto $\mathrm{CVI}$ cell monolayers in Costar micro plates. Four wells were inoculated for each dilution of virus. 
After I hour absorption at $37 \mathrm{C}$, cultures were refed with $\mathrm{E}+10$ and incubated at $37 \mathrm{C}$ lor $48-96$ hrs. The neutralization results were calculated according to the Reed and Muench method (Lennette and Schmidt, 1969). Isolates were also identified by an indirect immunollourescence test using ant-HSV type I and anti-HSV type 2 rabbit immune sera and goat antirabbit $\lg G$ conjugated with fluorescein isothiocyanate. Anti-HSV type $2 \mathrm{im}$ mune serum was absorbed with CVI cells infected with HSV type 1 to remove antigenic cross reactivity (personnal communication, A. Nahmias).

Human trigeminal ganglia from 44 cadavers in America have been processed in a similar manner, with 30 cases being explanted and cocultivated, with WI38 or CVI cells and 14 cases being explanted but not cocultivated. The significance of the difference of virus isolation rate from the trigeminal ganglia of Americans and Japanese was calculated by a Chi square test.

Human trigeminal ganglia for histopathological studies were obtanned from 10 young American adults 15-45 years old who were healthy until their sudden deaths due to trauma. Ganglia were removed bilaterally and divided into ophthalmic, maxillary, and mandibular portions. Each portion was immediately fixed in neutral phosphate-buffered $10 \%$ formalin and subsequently embedded in paraftin, sectioned at 6 micra, and stained by hematoxylin and eosin for light microscopy. Portions of these ganglia were not used for virus isolation studies. Trigeminal ganglia for histopathological studies were not removed from cadavers in Japan as these data have been reported previousy by Ishizaki (1972). The difference in the prevalence of mononuclear cell infiltrations of trigeminal ganglia in America and Japan was evaluated by calculation of the Chi square using Yates correction factor for small sample statistics.

Trigeminal ganglia were removed for electron microscopic studies from two young American adults who also died subequent to trauma and who showed no objective evidence of active HSV infections. Small pieces from the ophthalmic, maxillary, and mandibular portions of the four ganglia were fixed in $3 \%$ phosphate-buffered glutaraldehyde for 12-18 hours, and were then post-fixed in $1 \%$ phosphatebuffered osimum tetroxide for 1 hour. The pieces were then stained overnight in $1 \%$ aqueous uranyl acetate at $60 \mathrm{C}$. After dehydration, the tissue blocks were embedded in Epon 821. Ultrathin sections were stained with lead citrate and examined by transmission electron microscopy for evidence of virus particles.

\section{RESUITS}

RHL was reported by $35.6 \%$ of American adults and $24 \%$ of Japanese adults (Table 1). This difference was significant (Chi square $=5.4, \mathrm{p}<.02$ ) . No significant sex effect was observed.

HSV was isolated from 7 trigeminal ganglia obtained from 7 of $29\left(25^{\circ} ;\right)$ Japanese cadavers (Table 2). The first appearance of viral CPE occurred 8-16 days after explantation and cocultivation. The CPE was characterized by

\section{TABLE I}

Prevalence of Herpes Labialis Among Japanese and American Aclults

\begin{tabular}{|c|c|c|c|c|c|c|}
\hline \multirow[t]{2}{*}{ Country } & \multirow[t]{2}{*}{$\begin{array}{l}\text { \# Respondents } \\
\text { to Questionnaire }\end{array}$} & Total & \multicolumn{2}{|c|}{ remales } & \multicolumn{2}{|c|}{ Males } \\
\hline & & $\mathrm{YES}^{*} \quad \mathrm{NO}^{* *}$ & YES & No & YES & No \\
\hline USA & 146 & $\left|\begin{array}{cc}52 & 94 \\
(35.61 \%) & (64.38 \%)\end{array}\right|$ & $\begin{array}{c}28 \\
(35.9(\%)\end{array}$ & $\begin{array}{c}50 \\
(64.1 \%)\end{array}$ & $\begin{array}{c}24 \\
(35.3 \%)\end{array}$ & $\begin{array}{c}44 \\
(64.7(i)\end{array}$ \\
\hline JAPAN & 245 & $\left|\begin{array}{cc}59 & 186 \\
(24.08 \%) & (75.91 \%)\end{array}\right|$ & $\begin{array}{c}31 \\
(22.45 \% i\end{array}$ & $\begin{array}{c}107 \\
(77.53 c s)\end{array}$ & $\begin{array}{c}28 \\
(26.16 \% i)\end{array}$ & $\begin{array}{c}79 \\
\left(73.83{ }^{\circ}\right.\end{array}$ \\
\hline
\end{tabular}

* Positive history of RHL

*. Negative history of RHI.

TABLE 2

Isolation of HSV Iype I from Human Trigeminal Ganglia in Japan

\begin{tabular}{|c|c|c|c|c|c|c|}
\hline \multirow[t]{2}{*}{$\begin{array}{c}\text { Age } \\
\text { (yrs) }\end{array}$} & \multirow[t]{2}{*}{$\operatorname{Sex}$} & \multirow[t]{2}{*}{ Cause of Death } & \multirow[t]{2}{*}{$\begin{array}{c}\text { Trigeminal } \\
\text { Ganglion }\end{array}$} & \multicolumn{3}{|c|}{$\begin{array}{l}\text { Ratio* of Cultures Yielding V'irus } \\
\text { Explants Cocultivation }\end{array}$} \\
\hline & & & & glass & plastic & plastic \\
\hline 53 & $\mathrm{~F}$ & Uremia & $\mathrm{L}$ & ND & 1,1 & ND \\
\hline 6 & $\mathrm{~F}$ & Acute Leukemia & L & ND & 13 & ND \\
\hline 67 & M & Liver Cirrhosis & $\mathbf{R}$ & 0,2 & $0: 2$ & 1,1 \\
\hline 73 & $\mathrm{M}$ & Cancer of Stomach & $\mathrm{R}$ & $0 / 2$ & ND & 11 \\
\hline 65 & 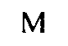 & Cancer of Lung & $\mathrm{R}$ & $0 / 1$ & ND & $1: 1$ \\
\hline 61 & $\mathrm{~F}$ & Polycystic Kidney & $\mathbf{R}$ & 0,2 & 12 & 01 \\
\hline 74 & $\mathrm{~F}$ & Hepatoma & L & 02 & 1.1 & $0 \quad 1$ \\
\hline
\end{tabular}

* Number of positive cultures/number of tested cultures

ND Not done.

TABLE 3

Isolation of HSl tipe I from the Trigeminal

Ganglia of American and Japanese Cadavers

\begin{tabular}{lllll}
\hline Total \# & \multicolumn{2}{c}{ USA } & \multicolumn{2}{c}{ Japan } \\
\hline Positive/Cases Tested & $22 / 44$ & $(50 \%)$ & $7 / 29$ & $(24 \%)$ \\
Positive/Ganglia Tested & $30 / 85$ & $(35 \%)$ & 752 & $(13 \%)$ \\
\hline
\end{tabular}


TABI.E 4

Histopathological Changes of American Human Trigeminal Ganglia

\begin{tabular}{|c|c|c|c|c|c|c|c|}
\hline \multirow[t]{2}{*}{ Case } & \multirow[t]{2}{*}{ Gianglion } & \multicolumn{3}{|c|}{ Mononuclear Cell Infiltration } & \multicolumn{2}{|c|}{ Ganglion Cell Abnormalities } & \multirow[t]{2}{*}{ Vascular Changes } \\
\hline & & $\begin{array}{c}\text { Ophthalmic } \\
\text { Portion }\end{array}$ & $\begin{array}{c}\text { Maxillary } \\
\text { Portion }\end{array}$ & $\begin{array}{c}\text { Mandibular } \\
\text { Portion }\end{array}$ & $\begin{array}{c}\text { Micro- } \\
\text { vacuolation }\end{array}$ & $\begin{array}{c}\text { Giant } \\
\text { Vacuoles }\end{array}$ & \\
\hline 1 & Left & - & + & + & + & + & - \\
\hline 2 & $\begin{array}{l}\text { Left } \\
\text { Right }\end{array}$ & $\begin{array}{l}+- \\
+\end{array}$ & - & + & - & - & + \\
\hline 3 & $\begin{array}{l}\text { Left } \\
\text { Right }\end{array}$ & $\begin{array}{l}- \\
-\end{array}$ & $\begin{array}{l}+ \\
+\end{array}$ & $\begin{array}{l}+ \\
+\end{array}$ & - & - & $\begin{array}{l}+ \\
+\end{array}$ \\
\hline 4 & $\begin{array}{l}\text { Left } \\
\text { Right }\end{array}$ & - & - & - & - & - & - \\
\hline 5 & $\begin{array}{l}\text { Left } \\
\text { Right }\end{array}$ & - & - & - & + & - & $\begin{array}{l}- \\
-\end{array}$ \\
\hline 6 & $\begin{array}{l}\text { Left } \\
\text { Right }\end{array}$ & $\begin{array}{l}+ \\
+\end{array}$ & + & $\begin{array}{l}+ \\
+\end{array}$ & + & + & + \\
\hline 7 & $\begin{array}{l}\text { Left } \\
\text { Right }\end{array}$ & - & + & - & - & - & + \\
\hline 8 & $\begin{array}{l}\text { Left } \\
\text { Right }\end{array}$ & $\begin{array}{l}+ \\
+\end{array}$ & $\begin{array}{l}+ \\
+\end{array}$ & $\begin{array}{l}+ \\
+\end{array}$ & $\begin{array}{l}+ \\
+\end{array}$ & - & + \\
\hline 9 & $\begin{array}{l}\text { Left } \\
\text { Right }\end{array}$ & $\begin{array}{l}- \\
+\end{array}$ & - & $\begin{array}{l}+ \\
+\end{array}$ & + & $\begin{array}{l}+ \\
+\end{array}$ & $\begin{array}{l}+ \\
-\end{array}$ \\
\hline 10 & $\begin{array}{l}\text { Lefi } \\
\text { Right }\end{array}$ & - & - & $\begin{array}{l}+ \\
+\end{array}$ & $\begin{array}{l}+ \\
+\end{array}$ & - & $\begin{array}{l}+ \\
+\end{array}$ \\
\hline
\end{tabular}

+ present

- absent

cell rounding, loss of cytoplasmic processes and formation of syncytia. Three virus isolations were from the left and 4 from the right trigeminal ganglia. Four isolations were obtained from explanted ganglion cultures, and 3 were from ganglion fragments cocultivated with African green monkey kidney cells. All viruses isolated were identified as HSV type 1 .

In America, 85 ganglia were obtained from 44 cadavers. HSV was isolated from 30 of the 85 ganglia. These 30 ganglia were obtained from 22 of the $44(50 \%)$ cases autopsied. In Japan, 52 ganglia were obtained from 29 cadavers and the 7 ganglia yielding HSV were obtained from 7 cadavers. The difference in virus isolation rate in America and Japan was statistically significant (Chi square $=3.86, \mathrm{P}=.05$ ).

Histopathological studies of ganglia from the American population disclosed a lymphocytic infiltration in ganglia in 8 out of 10 cases examined (Table 4 and figure 2). These infilt rates were diffuse in some specimens and focal in others. When focal, they tended to involve the mandibular portion of the ganglion more frequently than the ophthalmic or maxillary portions. The difference in incidence of lymphocytic infiltration between 8 of 10 American cadavers and the 36 of 71 cadavers reported by Ishizaki (1972) in Japan is not significant (Chi square $=1.92, \mathrm{P}>.1$ ). A second histopathological observation consisted of cytoplasmic vacuolization of ganglion cells. This took the form of microvacuoles in 9 of 10 cases and larger or giant vacuoles in 4 of 10 cases. A third abnormality consisted of thickening and hyalinizatin with multilamellar change in the walls of intrinsic arteries and arterioles (figure 3). The lumina of these vessels were frequently reduced in size and a scanty lymphocytic infiltration in the walls of affected vessels was sometimes seen. No inclusion bodies were found. Preliminary electron microscopic studies on four human trigeminal ganglia have failed to detect virus particles. Further studies are in progress.

\section{DISCUSSION}

On the basis of our retrospective questionnaire study, it appears that RHL is significantly less common in Japan than in the northern United States. This conclusion is in agreement with a Canadian study (Embil et al., 1975) that also suggested a lower prevalence of RHL in Asia (less than $20 \%$ of young adults) than in North America (40\% of young adults). Less frequent $\mathrm{RHL}$ in Japanese than in Americans could theoretically be due to less frequent infection of the Japanese by HSV or a relative resistance of the Japanese to overt diseases caused by $\mathrm{HSV}$.

We have been successful at isolating HSV type I from 22 of 44 American cadavers and from 7 of 29 Japanese cadavers. This difference in isolation rate is barely significant. However, the difference in the HSV infection rate of trigeminal ganglia of Americans and Japanese may be even greater than is suggested by the rescue of spontaneously released HSV from explanted and cocultivated ganglia. For 
example, 23 American ganglia that did not spontaneously release $\mathrm{HSV}$ were shown to have latent HSV genome in 11 instances when the cells were superinfected with thermo-sensitive mutants of HSV (Brown et al., 1978), whereas 13 Japanese ganglia that had not released $\mathrm{HSV}$ have shown no evidence of latent HSV genome when the cells were similarly superinfected. These observations seem to suggest that Japanese trigeminal ganglia are less commonly latently infected by HSV than American trigeminal ganglia. A larger series of virus isolation studies in the two countries are required in order to further clarify this possibility.

Our virus isolation studies were performed on Japanese cases with severe chronic disease prior to death, whereas the American cases were in most instances healthy until sudden deaths due to trauma. However, we do not think this lowered the HSV recovery rate from the Japanese ganglia since reports of the recovery rate of HSV from American cases with debilitating diseases are similar to our findings (Baringer and Swoveland, 1973; Forghani et al., 1977). The low HSV isolation rate from the Japanese trigeminal ganglia in conjunction with the frequent presence of antibodies to HSV in this population may be suggesting that the virus is latent in other sites. We have recently isolated HSV from the superior cervical and vagus ganglia of American cadavers (Warren et al., 1978), and it is therefore possible that ganglia other than the trigeminal could be a more common site of latent HSV in the Japanese population.

We have identified mononuclear cell infiltrations in the majority of human trigeminal ganglia. The exact function of the lymphocytic plasma cell infiltration in trigeminal ganglia is currently unknown. The immunological response has been shown to restrict the number of HSV-infected cells in sensory ganglia infected with HSV (Walz et al., 1976). It is possible that an adequate lymphocytic and plasma cell infiltration within anatomical sites where there is clinically latent virus is necessary to prevent excess proliferation of virus and subsequent infection of a large number of cells. If $\mathrm{HSV}$ is the only virus present in a latent form in human trigeminal ganglia and if the lymphocytic infiltration occurs only in ganglia infected with HSV, then the rates of latent infection of trigeminal ganglia with HSV in Japan and America may be higher than reported here. It is also of interest that in the Japanese study (Ishizaki, 1972) the mononuclear cell infiltration involved not only the trigeminal ganglia in 36 of 71 cases, but also involved the trigeminal nerve roots in 11 of the 36 cases with infiltration of the ganglia, and lymphocytic perivascular cuffing was present in the area of the superior sensory nucleus of the trigeminal nerve in the pons in 2 of the 36 cases. We have observed lymphocytic infiltrations in the trigeminal ganglia, trigeminal nerve roots, and adjacent trigeminal nuclei in the pons in three unselected cadavers in America. These observations may be a histopathological clue that the herpesviruses are capable of migrating from the peripheral nervous system ganglia to the central nervous system of humans.
Our histopathological studies of the trigeminal ganglia of humans have also demonstrated vascular abnormalities and vacuolar degeneration of ganglion cells. That the vascular abnormalities could theroretically be due to an infectious agent is suggested by research from our laboratories that demonstrated similar vascular abnormalities in the brains of mice and chimpanzees inoculated with a parainlluenza type $1(6 / 94)$ virus (Rorke et al., 1976; lief et al., 1976). Vacuolar degeneration of ganglion cells can be observed in spinal and sympathetic ganglia, and the giant vacuoles are thought to be due to confluence of the smaller ones as they get progressively larger and surface tension is reduced (DeCastro, 1932a; DeCastro, 1932b). Vacuolar change of ganglion cells can be observed in apparently normal humans as well as in humans with a variety of noninfectious and infectious diseases (section of nerves, pellagra, amaurotic idiocy, Korsakoft's psychosis and tabes dorsalis). Since experimental

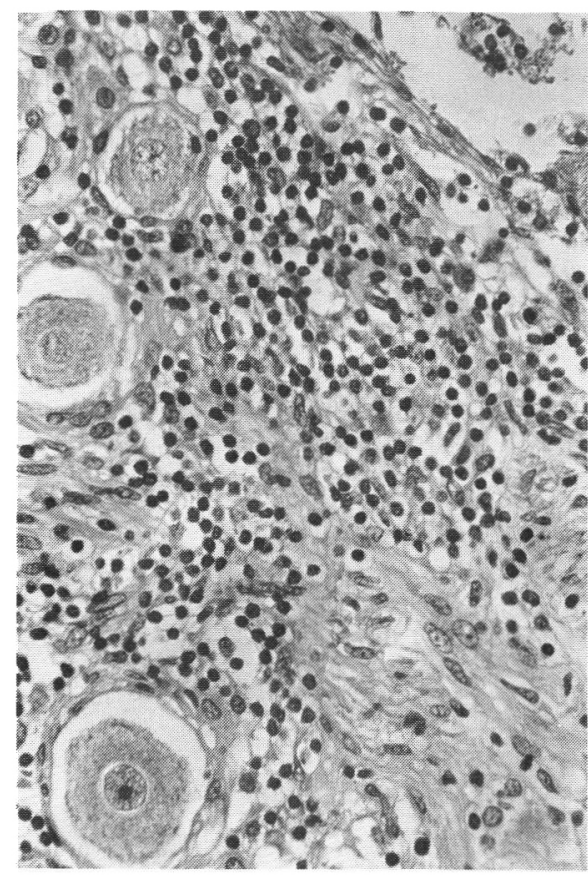

Figure 2. - Lymphocytic infiltration in trigeminal ganglion of an apparently healthy male victim of an automobile accident. Hematoxylin and eosin. 100X.

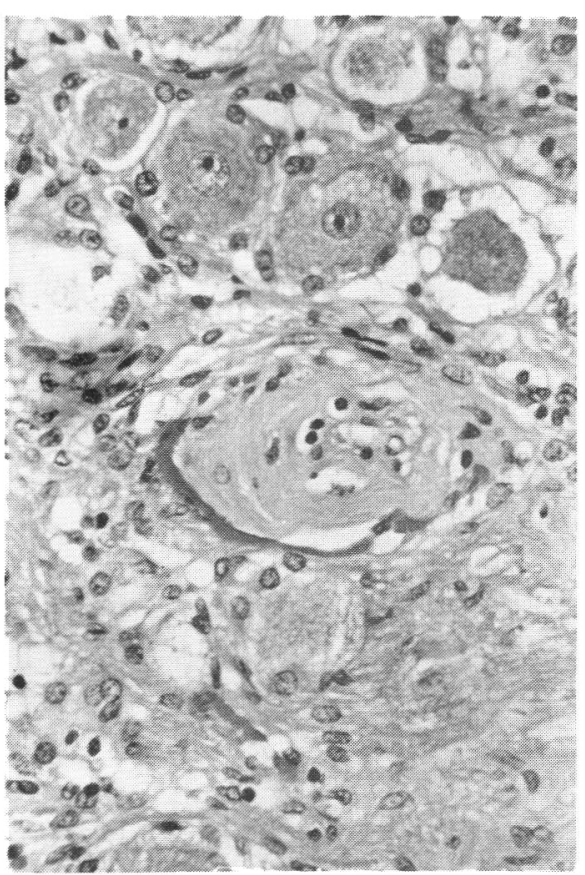

Figure 3. - Arteriolar degeneration showing hyalinzation with lamination of wall and incarceration of lymphocytes within damaged vessel wall. Hematoxylin and eosin. 200X. 
induction of vacuolar change in the trigeminal ganglion cells of rabbits can be produced by infection with HSV (Baringer and Swoveland, 1974), it can be questioned whether the vacuolization of human trigeminal ganglion cells may at least in part be due to HSV.

In summary, our study suggests that RHL is significantly less common in Japanese persons than in Americans, and that HSV can be recovered less commonly from the trigeminal ganglia of Japanese than from Americans. Furthermore, mononuclear cell infiltrations of the trigeminal ganglia occurs in $50 \%$ of Japanese and perhaps as high as $80 \%$ of Americans. This pathological observation may be suggesting that clinically latent virus is present in $50 \%$ of Japanese and $80 \%$ of Americans. Additional studies are required to confirm these observations.

\section{ACKNOWLEDGEMENTS}

The authors would like to thank Dr. T. I wasaki and Dr. T. Okabe for collecting the data on the prevalence of recurrent herpes labialis in Japan and M. Devlin. K. Harada, A. Jackson, Y. Kawahata, J. Poppel, and J. Tanaka for their assistance in the performance of this research. The statistical analysis was performed by Dr. S.A. Warren.

This study was supported in part by grants from the National Multiple Sclerosis Society. USPHS research grants NS 11036 from the National Institute of Neurological and Communicative Diseases and Stroke and RR 05540 from the Division of Research Resources and the Multiple Sclerosis Society of Canada.

\section{REFERENCES}

ANDREWES, C. H. and CARMICHAEL, M. B. (1930). A Note on the Presence of Antibodies to Herpes Virus in Post Encephalitic and Other Human Sera. Lancet. 1:857-858.
BARINGER, J. R. and SWOVELAND, P. (1973). Recovery of Herpes Simplex Virus From Human Trigeminal Ganglions. New Eng. J. Med. 288:648-650.

BARINGER, J. R, and SWOVELAND, P. (1974). Persistent Herpes Simplex Virus Infection in Rabbit Trigeminal Ganglia. Lab. Invest. 30:230-240.

BROWN, S. M., JAMIESON, A. T., SUBAKSHARPE, J. H., et al. (1978). Detection of Defective or Uninducible HSV Genomes Latent in Human Trigeminal Ganglion Explants. Heredity, in press.

DeCASTRO, F. (1932a). Sensory Ganglia of the Cranial and Spinal Nerves: Normal and Pathological. In: "Cytology and Cellular Pathology of the Nervous System", Penfield, W. (editor). New York, Hafner Pub. Co.

DeCASTRO. F. (1932b). Sympathetic Ganglia: Normal and Pathological. In: "Cytology and Cellular Pathology of the Nervous System", Penfield, W. (editor), New York, Hafner Pub. Co.

EMBIL, J. A., STEPHENS, R. G. and MANUEL F. R. (1975). Prevalence of Recurrent Herpes Labialis and Aphthous Ulcers Among Young Adults on Six Continents. Canadian Med. Assoc. J. 113:627-630.

FORGHANI, B., KHASSEN, T. and BARINGER, J. R. (1977). Radioimmunoassay of Herpes Simplex Virus Antibody: Correlation with Ganglionic Infection. J. Gen. Virol. 36:371-375.

HONDO, R. (1974). A Seroepidemiological Study of Herpes Simplex Virus. Japan J. Med. Sc. Biol. 27:205-213.

ISHIZAKI, T. (1972). Lymphocytic and Plasma Cell Infiltration in the Human Trigeminal Ganglia. Clinical Neurol. 112:596-600.

LENNETTE, E. H. and SCHMIDT, N. J. (1969). Diagnostic Procedure for Viral and Rickettsial Infections. Fourth Edition. Amer. Publ. Health Assoc. Inc.
LIEF, F. S., RORKE. L. B., KALTER, S. S., et al. (1976). Infection and Disease Induced in Chimpanzees with 6/94, a Parainfluenza Type I Virus Isolated from Human Multiple Sclerosis Brain. J. Neuropath. Exp. Neurol. 35:644-664.

RORKE, L. B., GILDEN, D. H., WROBLEWSKA. Z. and WOLINSKY.J. S. (1976). Experimental Panencephalitis Induced in Suckling Mice by Parainfluenza Type I (6/94) Virus. I. Clinical and Pathological Studies. J. Neuropath. Exp. Neurol. 35:247-258.

SHIP, I. I., MORRIS, A. L., DUROCHER, R.T. and BURKET, L.W. (1960). Recurrent Autochthonous Ulcerations and Labialis in a Professional School Student Population. I. Experience. Oral Surg. 13:1191-1202.

WALZ, M.A., YAMAMOTO, H. and NOTKINS, A. L. (1976). Immunological Response Restricts Number of Cells in Sensory Ganglia Infected with Herpes Simplex Virus. Nature 264:554-556.

WARREN, K. G., BROWN, S. M., WROBLEWSKA. Z.. et al. (1978). Isolation of Latent Herpes Simplex Virus from the Superior Cervical and Vagus Ganglia of Humans. New Eng. J. Med. 298:1068-1069.

WARREN, K. G.. DEVLIN, M., GILDEN, D. H.. et al. (1977). Herpes Simplex Virus Isolation from Human Trigeminal Ganglia Including One Case of Multiple Sclerosis. Lancet 2:637-639.

WARREN, K. G.. PATY. D. W.. MCFARLANE, M. and WARREN, S. A. (1976). Herpes Labialis and Multiple Sclerosis. Lancet 1:1193.

YOSHINO, K., TANIGUCHI. S., FURUSE, R., et al. (1962). A Serological Survery of Antibodies Against Herpes Simplex Virus with Special Reference to Comparatively Heat-labile Complement Fixing Antibodies. Japan J. Med. Sc. Biol. 15:235-247. 